\title{
Ecotour providers in the Kyushu region: the characteristics of Japanese ecotourism and its relationship with global warming*
}

\author{
YUKIO YOTSUMOTO
}

\begin{abstract}
Ecotourism is a type of tourism that is popularly regarded as an environment-friendly activity. Thus, we tend to think that it has a positive relationship with climate change. However, in Western literature, many studies indicate that ecotourism is not environment-friendly in terms of climate change, and that it actually contributes to global warming substantially owing to the use of airplanes by tourists. In Japanese scholarship, there is no substantial research on this topic. This paper reports on a study in which three methods were used to evaluate the relationship between ecotourism and climate change in the Kyushu region of Japan: content analysis, a mail survey, and participant observation. The results indicate that it is a tenuous positive relationship but a varied negative relationship; that is, the impact depends on the type of ecotourism. The ecotour providers in Kyushu do not have explicit ideas on how ecotourism relates to global warming, and their actual contribution toward a low-carbon society is limited to activities such as consumption of locally produced foods, recycling lunch boxes, and using less fossil fuel during tours. Discussed is the existence of a positive but weak relationship and a variegated negative relationship in Japan together with the negative relationship emphasized in Western literature. The conclusions suggest that Japanese ecotourism's emphasis on revitalization of local communities influenced the formation of a varied negative relationship to a certain degree.
\end{abstract}

Keywords: ecotourism; low-carbon society; revitalization; environmental education; Kyushu.

\section{Introduction}

Climate change is a high-priority issue for many industries; for example, the manufacturing sector has implemented recycling programs and 
installed more energy-efficient equipment to curb the emission of greenhouse gases. In contrast, the tourism sector around the world has been slow to address the problem due to its amorphous nature; it is a mixture of established industries such as transportation, lodging, food service, travel, and the like. It is not clear where the responsibility for climate change lies. Among the various types of tourism, ecotourism is slower to address the problem because it is commonly viewed as an environmentally friendly type of tourism. Global warming has become one of the top political and social issues to be solved, as evidenced by the annual United Nations Climate Change Conferences. Japan assumed an important role in the adoption of the Kyoto Protocol in 1997, which aimed to stabilize the concentration of greenhouse gases in the atmosphere. On 22 September 2009, Prime Minister Hatoyama Yukio announced that Japan had set the goal of reducing the level of greenhouse gases to $25 \%$ below 1990 levels by 2020 (Asahi Shimbun 23 September 2009). To achieve this goal, government, industry, and citizens have to implement measures to lower emissions of greenhouse gases. The tourism sector also needs to implement emission reduction measures.

Ecotourism is a type of tourism that considers the environment. Definitions of ecotourism vary (Goeldner and Ritchie 2009: 483), but many include the concepts of protection of nature and consideration for local people. Although ecotourism is concerned with the environment, it does not necessarily mean that ecotourism contributes to the reduction of greenhouse gases, as popularly envisaged, because consideration for the environment has many dimensions, and it is possible that ecotourism organizers or providers do not fully understand the dimensions of the term "environment". When the United Nations World Tourism Organization (UNWTO) studies and promotes ecotourism, its discussions center around the impact on the local environment, economy, and society, while tending to ignore the global effects of ecotourism (Becken and Schellhorn 2007: 86). In ecotourism, there is a gap between environmental concern at a local level and inconsideration of the environment at a global level (Gössling et al. 2002: 200). Therefore, it is important to assess its impact both globally and locally.

The study has three parts. First, the existing literature on the relationship between tourism and global warming is reviewed, especially ecotourism's connection with the latter in the West and Japan. Second, based on qualitative research, it will be assessed whether there exists a relationship between ecotourism and climate change in the Kyushu region of Japan. In other words, the causal direction from ecotourism to climate change will be looked at, and whether ecotourism contributes 
to global warming or the reduction of greenhouse gases. Third, the findings will be analyzed and interpreted by specifically looking at the unique characteristics of Japanese ecotourism.

\section{Literature review}

\subsection{Impact studies on tourism and climate change}

In the tourism sector, the efforts to reduce greenhouse gases have been slow compared to the manufacturing sector. For example, no travel company finds a mention in the "Corporate Knights Global 100 Most Sustainable Corporations" list reported by Corporate Knights in Canada, a magazine that promotes clean capitalism (Kunori and Kobayashi 2007b: 353). Moreover, tourism had a marginal position in terms of negotiations and discussions at the United Nations Climate Change Conference in Bali, Indonesia, in December 2007 (Becken 2008: 246).

The slow reaction of the tourism sector to global warming is partially due to the slow start of the investigation into the relationship between tourism and climate change, especially the investigation into the contribution of tourism to global warming. Studies on the relationship between climate change and tourism emerged during the 1990s in parallel to the publication of the First and Second Assessment Reports of the United Nations Intergovernmental Panel on Climate Change in 1990 and 1996 (UNIPCC 1990, 1996). Most of the studies were conducted to reveal the impact of climate change on tourism (Scott et al. 2005), and the reports have provided a major research direction in the field. Researchers have studied destinations that will be affected most by the increase in temperature. The destinations vulnerable to climate change often overlap with ecotourism destinations. The majority of the presentations at the First International Conference on Climate Change and Tourism in Tunisia in April 2003 were from the causal direction from climate change to tourism, such as the impact of climate change on tourism in coastal and mountain areas (WTO 2003). The book edited by Hall and Higham (2005) is also filled with cases of this causal direction in areas such as the Mediterranean, the Scottish Highlands, and the Alps. More recently, Stewart and Draper (2009) have studied the impact of global warming on cruise tourism in Arctic Canada. They identify the retreat of the Arctic sea ice and increased ice hazards to shipping as phenomena caused by global warming, which also influence cruise tourism. The phenomena encourage more tourists to visit the Arctic to appreciate its beauty before it vanishes.

After the turn of the century, studies focusing on the opposite causal direction - that is, the effects of tourism on climate change - began 
to appear (see Becken and Simmons 2005: 192). Gössling (2000) set a tone for the new direction by criticizing the lack of discussion in sustainable tourism development literature about tourism's negative impact on global warming due to the sector's energy use. Becken (2002) looks at the impact of international air travel in terms of national energy use and carbon dioxide emissions in New Zealand. She widened the scope of the issue by studying tourists' perception of international air travel's impact on climate change policies (Becken 2007). Methodological discussions were widely held on the ways to calculate greenhouse gas emissions by travel components and types of transportation (Becken and Hay 2007; Bonner 2005). The tourism sector's principal contributor to global warming was identified as transportation (Holden 2009: 17; WTO 2003: 11), with air transportation identified as the biggest contributor with 515 megatons of carbon dioxide emissions in 2005. In tourism, $75 \%$ of the total greenhouse gas emissions come from transportation (WTO and UNEP 2008: 132, 146). Ecotourism, a type of tourism that is regarded as a guardian of the environment, is no exception. Although it contributes to conservation of nature in local communities, ecotourism also contributes to air pollution, noise pollution, and global warming through the use of transportation (Buckley 2009: 657). Gössling et al. (2002) and Hunter (2009) use ecological footprint analysis to measure the magnitude of ecotourism's contribution to global warming. In this area, a consensus on the impact emerged that ecotourists flying to their destinations contribute to the problem of global warming to the same extent as mainstream travelers (Wearing and Neil 2009: 224), or even that ecotourism is responsible for more greenhouse gas emissions than other conventional types of tourism, such as resort-based tourism (Becken and Schellhorn 2007: 87).

In the study of tourism's impact on climate change, the reciprocal relationship of climate change on tourism became an important consideration. The First International Conference on Climate Change and Tourism in 2003 concluded the need to recognize a two-way relationship between tourism and climate change (WTO 2003: 10). An example of this perspective is a study by Dawson and colleagues (2010) on polar bear viewing tourism in Churchill, Canada. Viewing polar bears requires long-haul air travel, which emits carbon dioxide. Global warming that is partially caused by this tourism negatively influences the population of polar bears, the main resource of this tourism. Paradoxically, the possible decline of polar bear population alarms tourists, who rush to see the polar bears before it is too late, resulting in a further increase of carbon dioxide emissions. This is one of the worst cases of the environmental impact of ecotourism, wherein negative consequences are intensified from both directions. 


\subsection{Studies on practices to reduce greenhouse gas emissions in tourism}

Following an understanding of the reciprocal relationship between tourism and climate change, the focus moves to studying ways to reduce tourism's contribution to global warming. Martha (2008: 42) describes efforts to reduce greenhouse gas emissions by airline companies. Major airline companies typically decrease emissions in the form of fuel efficiency, which also reduces their operating costs. JetBlue, a US carrier, replaced their fleet with planes that were $50 \%$ more efficient. Japan Airlines also took action by initiating a recycling program and purchasing more energy-efficient airplanes. International, regional, and national organizations, such as the International Air Transport Association (IATA) in Europe, and the US Federal Aviation Administration (FAA), also try to create a business environment in which each airline company can speed up its fuel efficiency initiatives to reduce emissions of greenhouse gases (Martha 2008: 42). The United Nations Intergovernmental Panel on Climate Change estimates that there will be a $20 \%$ reduction in emissions between 1997 and 2015, and a $30 \%$ to $50 \%$ reduction in emissions between 1997 and 2050, assuming that aircraft engines and airframes are improved (Penner et al. 1999). However, these estimates look challenging to achieve for two reasons. First, the demand for air transportation is growing rapidly. For example, according to Boeing's estimate, there were about 19,000 commercial airplanes flying in the world in 2009; however, in 20 years, there will be 36,000 commercial airplanes (Asahi Shimbun 17 November 2010). Second, the development of new energy-efficient airplanes is not as smooth as we might expect. For example, Asahi Shimbun reported that two major airplane manufacturing companies, Boeing and Airbus, have faced a series of obstacles in test flights of their new airplanes, the Boeing 787 and Airbus A380, both of which were designed to improve fuel efficiency (Asahi Shimbun 17 November 2010).

Policy-oriented research in this field has been disseminated by many scholars. For example, Strasdas (2007) discusses voluntary offsetting of flight emissions as a possible approach to reduce the negative impact of long-haul tourism. Gössling and colleagues (2007) evaluate various organizations that offer voluntary carbon offsetting schemes to airline companies and found their ambiguous nature as a tool and solution. They conclude that the voluntary carbon offsetting schemes need to be clarified and regulated in order to be effective in reducing greenhouse gas emissions by long-haul tourism. Thus, a positive relationship between ecotourism and climate change is inconclusive in Western literature. 


\subsection{Japanese studies on ecotourism and climate change}

In the case of Japanese scholarship, not many studies have been conducted on the relationship between ecotourism and global warming. In the causal direction from climate change to ecotourism, Watanabe (2004: 185) shows the negative impacts of global warming on the establishment and development of mountain ecotourism in the Kangchenjunga Conservation Area in Nepal through the occurrence of hazards, such as rockfalls, debris flow, and avalanches, and through the disappearance of alpine plants and animals like the snow leopard. In a comparative study between Lakes Shinji and Nakaumi (brackish water) in Shimane Prefecture and ecotourism areas in Oki, Okinawa in Japan, Phuket in Thailand, and Lago de Atitlan (Atitlan Lake) in Guatemala, Tsuzuki and colleagues (2009: 11) conclude that ecotourism in Lakes Shinji and Nakaumi is potentially vulnerable to climate change.

In the causal direction from tourism (not necessarily ecotourism) to climate change, Kunori and Kobayashi (2006, 2007a, 2007b) study the impact of tourism on climate change using a hypothetical 3-day/2-night trip from Tokyo to Yakushima, Kagoshima Prefecture. It shows that $96 \%$ of $\mathrm{CO}_{2}$ emissions in the trip is due to transportation from Tokyo to Yakushima, $1 \%$ to accommodation, and 3\% to transportation within the island. Their study is hypothetical and the paper developed based on their study is very brief and is not comprehensive. Moreover, Shikida (2009: 24) briefly discusses carbon-offsetting programs by Japanese travel companies, such as JTB and Odakyu Travel and Odakyu Railway Company, in an essay (not research).

Literature review indicates that, in the case of Japanese scholarship, understanding the impact of ecotourism on climate change remains in the preliminary stage. There are no studies that investigate ecotourism providers' perception and assessments of ecotours' impact on climate change in Japan.

\subsection{Summary}

In countries such as Canada and New Zealand, where ecotours are based on the Western conception of ecotourism, there is a strong negative relationship between ecotourism and global warming. Through an estimation of the emission of carbon dioxide caused by air travel, or an interpretation of the perceptions of travelers on air travel's impact on climate change, scholars concluded that, due to the use of airplanes to distant destinations, ecotourists contribute to global warming as much as or more than other types of tourists. In the case of Japanese 
scholarship, there is no substantial research conducted on the link between ecotourism and global warming. Thus, the following sections try to evaluate this issue in the case of Japanese ecotourism.

\section{Methods}

In order to find out if a link between Japanese ecotourism and climate change exists, the perception and practices of ecotour providers were examined by analyzing both primary and secondary data. The data were collected using three methods: content analysis, a questionnaire survey sent out by mail, and participant observation, which included an informal interview. To promote ecotourism in Japan, the Ministry of Environment has created the most comprehensive list of ecotour providers in Japan through the "Ekotsuā sōran" ('Surveying ecotours') Web site. ${ }^{1}$ As of 25 August 2010, there were 54 ecotour providers located in the Kyushu region; in terms of prefecture, there were 3 in Fukuoka, 1 in Saga, 4 in Nagasaki, 5 in Kumamoto, 1 in Oita, 2 in Miyazaki, and 38 in Kagoshima. The profile and features of every organization's ecotours is listed. The contents were analyzed with regard to the association between ecotourism and climate change. A questionnaire survey was also conducted by mail to 54 organizations ( 2 could not be delivered) with a response rate of $40.38 \%$. It consisted of openended questions to obtain basic information about the organization and ecotours, tourists' mode of transportation, as well as their perceptions of ecotourism in regard to climate change. In addition, in February 2011, the author participated in an ecotour in Sasebo city, Nagasaki Prefecture, which was offered by one of the organizations that participated in the mail survey. As this research topic was new, multilayered research methods are most appropriate to ensure validity. The findings presented below are based on the data gathered by these three methods.

\section{Findings}

\subsection{Content analysis of the "Ekotsuā sōran" Web site}

The content analysis reveals that 21 remarks related to the realization of a low-carbon society are found, which were made by only 17 of the 54 organizations. The topics can be categorized into three types (see Table 1). The first type is related to lifestyles that may contribute to a low-carbon society. Under this category, there are two subcategories: alternative energy usage and consumption of locally produced foods. Only two organizations mentioned the use of alternative energy. The examples are an experience of farming through the use of manual la- 
Table 1. Discourse on the realization of a low-carbon society on the "Ekotsuā sōran" Web site.

\begin{tabular}{|c|c|c|c|c|}
\hline & Type & $\begin{array}{l}\text { No. of } \\
\text { statements }\end{array}$ & Subcategory & $\begin{array}{l}\text { No. of } \\
\text { statements }\end{array}$ \\
\hline 1 & \multirow[t]{2}{*}{ Lifestyle } & \multirow[t]{2}{*}{11} & Alternative energy use & 2 \\
\hline 1 & & & $\begin{array}{l}\text { Consumption of locally } \\
\text { produced foods }\end{array}$ & 9 \\
\hline 2 & New technology & 3 & - & 3 \\
\hline \multirow[t]{2}{*}{3} & \multirow{2}{*}{$\begin{array}{l}\text { Concern for } \\
\text { nature }\end{array}$} & \multirow[t]{2}{*}{7} & Reforestation & 3 \\
\hline & & & Environmental education & 4 \\
\hline
\end{tabular}

bor, and ecotours that use public transport (railroad and ships), and a hike. These are practices developed by directly targeting a reduction in greenhouse gases. The latter is a growing trend in Japan. Consumption of locally produced foods is promoted throughout Japan in order to foster a healthy diet and revitalize local agriculture. The movement also contributes to the realization of a low-carbon society by reducing food mileage (Norberg-Hodge 1998), although many Japanese may not purchase food for that purpose. The ecotour operators integrate this trend into their products, although the primary purpose of its introduction is the revitalization of local agriculture. This is the most popular subcategory, mentioned by nine organizations. The second type is new technology, mentioned by only three organizations. Instead of relying on fossil fuels, ecotour operators try to use energy generated by solar power systems or thermal energy stored in the buildings that accommodate tourists. The third type is concern for nature. This type is divided into two subcategories: reforestation and environmental education. Three organizations have projects to restore the environment of the areas they use. Although ecotourists do not participate in actual reforestation, their money is used for reforestation projects. Four organizations use ecotours to promote environmental education. For example, an ecotour to Mount Aso in Kumamoto Prefecture is designed to ignite the idea of conservation and restoration of the grasslands in Aso. This latter type of ecotour raises questions such as "why do we have to think about the environment?" and "what should we do to protect the environment?" as an important starting point for action (Hori 2007: 2).

The content analysis of the Ekotsuā sōran Web site indicates that only $31 \%$ (17) of the ecotour providers in Kyushu have activities that may contribute to the realization of a low-carbon society. These 17 providers provided 21 statements related to the reduction of greenhouse gases. However, it seems that 13 activities ( 9 for consumption of 
locally produced foods and 4 for environmental education) stated in the Web site were not developed by the ecotour providers consciously targeting the reduction of carbon dioxide. Only 8 activities ( 2 for alternative energy use, 3 for new technology, and 3 for reforestation) were developed for the purpose of reduction of greenhouse gases. This finding indicates that the link between Japanese ecotourism and climate change in a positive direction (contribution toward a low-carbon society) is tenuous. Moreover, Ekotsuā sōran functions as a site to market ecotours; thus, it does not include contents that reveal the relationship between ecotours and climate change in a negative way.

\subsection{Analysis of the mail survey}

4.2.1. Profiles of ecotour providers. Ecotour providers in Kyushu are small organizations with an average of 5.26 staff (including part-time). In terms of type, $68.4 \%$ are for-profit organizations, whereas $31.6 \%$ are non-profit. Non-profit organizations have more staff members than forprofit organizations. However, in general, the organization type does not have any relationship with the number of ecotours provided or the price of a tour. The providers offer ecotours 174.6 times a year on average. One provider conducts only two ecotours a year, whereas another organization provides 1,250 tours a year. Approximately $50 \%$ of the providers conduct ecotours less than 80 times a year. The price of a tour ranges from 0 yen (non-profit) to 30,000 yen with 9,427.8 yen on average. About $50 \%$ of the providers set a tour price of less than 5,000 yen. The number of ecotour participants per year ranges from 60 to 7,250 , and $1,073.1$ on average. About $50 \%$ of the providers have less than 400 participants a year. Ecotourism is not a very profitable business. The sale is only 3,103,076 yen per employee a year on average.

A look at the origin of the participants reveals that $43.4 \%$ are from outside Kyushu, especially from Tokyo and Kansai areas, followed by participants from within the prefecture $(28 \%)$. The most popular means of transportation to the destinations was airplane $(50 \%)$, followed by car $(39 \%)$. However, the most popular mode of transportation during the tours was walking $(68.4 \%)$, followed by ship $(10.5 \%)$ and car $(10.5 \%)$. Since Yakushima is a remote island in Kyushu, there is a relationship between the mode of transportation and the destination (Yakushima or not). Ecotourists who visit Yakushima use airplanes, whereas ecotourists who visit other places tend to use cars, trains, and ships to reach their destinations. However, there is no relationship between the mode of transportation during the tours and the destinations (Yakushima or not). This finding indicates that the relationship between ecotours and climate change in a negative way de- 
pends on the type of ecotour ("Yakushima" type or "non-Yakushima" type). Ecotours in Yakushima contribute to global warming because of tourists' heavy reliance on air transport to travel there. On the other hand, ecotours of "non-Yakushima" type have less impact on global warming, as tourists tend to use means of transportation other than airplanes.

4.2.2. The relationship between ecotours and climate change. The content analysis of the Ekotsuā sōran Web site (Section 4.1) was made from the author's perspective (interest) despite the fact that the ecotour providers developed the Web contents without considering the issue of global warming. Therefore, this section specifically investigates the ecotour operators' perception of, and activities concerning, the issue.

Among 21 ecotour providers who responded to the questionnaire, only one respondent (who operated in Yakushima) perceived the link between ecotourism and global warming in a negative way, although this provider also commented on the link in a positive way. For the negative link, this provider commented that "to go to the destination by car and to enter the nature accompanying people (tourists) burden the natural environment". This suggests that although ecotours in Yakushima have a negative link owing to the use of air transport to the destination, ecotour operators in Yakushima are not aware of this link. On the other hand, all the providers who responded to the question on the link commented on the association between ecotourism and climate change in a positive way. The ecotour providers in Kyushu expect that, in general, ecotours contribute to the realization of a low-carbon society through environmental education, reduction of energy, and protection of forests. Among these approaches, environmental education is the most addressed, with 14 comments $(77.8 \%)$, followed by reduction of energy ( 3 comments, $16.7 \%$ ), and protection of forests ( 1 comment, $5.5 \%)$. Table 2 lists some examples of the comments.

In this survey, the relationship between their own ecotours and climate change was also asked. This question elicited fewer comments than the comments for the earlier general question, with 13 comments on environmental education, two comments on reduction of energy, and no comments on protection of forests. Furthermore, no provider remarked on the negative relationship. Examples of the positive relationship included the following: About environmental education, one ecotour provider said, "We only expect a change in participants' consciousness. We expect them to have fun and feel healed. We expect them to seek more knowledge on the nature and to respect it. We expect them to think about ways to reduce $\mathrm{CO}_{2}$ on their own". For 
Table 2. General comments by ecotour providers on the relationship between ecotours and the realization of a low-carbon society.

\begin{tabular}{ll}
\hline $\begin{array}{l}\text { Environmental } \\
\text { education }\end{array}$ & Through ecotourism, we inform and educate people on \\
& how to interact with the environment. That is an ideal! \\
- & We let people know the conditions of the natural \\
& environment through a natural experience. \\
- & Ecotours help build awareness of the importance of \\
& nature. \\
- & Ecotours create a space for education on \\
& environmental protection. \\
Reduction of energy & - Provide tours that do not use fossil energy. For \\
usage & example, take a walk or use a bicycle or a canoe. \\
Protection of forests & - Propose an electric car for a tour. \\
& A tour of the forests for those who buy trees for \\
& building a house. (Buying local trees will protect the \\
& logging industry that manages forests.) \\
\hline
\end{tabular}

reduction of energy, another ecotour provider uses a lunch box made of bamboo leaves. This is a washable box, and when tourists return it, they receive 50 yen. Since it is recyclable, using it will save energy. Yet another organization asks tourists to use public transport to reach a meeting place for a tour. To encourage such use, they do not build a parking lot for tourists.

As indicated earlier, when asked about the relationship between their ecotours and global warming, they do not perceive any negative relationship between them. On the positive relationship, they think that their ecotours can have a positive impact on the realization of a lowcarbon society through environmental education (13 comments, $86.6 \%$ ) and reduction of energy ( 2 comments, $13.3 \%$ ). However, the effect of their environmental education is long-term and difficult to measure. On the other hand, programs that actually target reducing $\mathrm{CO}_{2}$ in ecotours are not practiced widely. The study revealed that only two practical measures to reduce $\mathrm{CO}_{2}$ were conducted: use of a bamboo lunch box and guidance to use public transport. The former is well intentioned, but its contribution to reduce $\mathrm{CO}_{2}$ is limited. What can be observed here is the ecotour providers' difficulty in actually implementing measures that bring substantive results in reducing $\mathrm{CO}_{2}$. Thus, analysis of the mail survey indicates that the relationship between Japanese ecotourism and climate change is tenuous in a positive way. For a negative relationship, we have to look at the transportation factor, which will be discussed later. 


\subsection{The case of Saikai Pearl Sea Resort, an ecotour operator in Sasebo, Nagasaki}

This section discusses ecotourism held at Saikai Pearl Sea Resort in Sasebo city (population: 260,826 as of February 2011), Nagasaki Prefecture, using data obtained from the mail survey, and participant observation that included an informal interview. Among the respondents to the mail survey, Saikai Pearl Sea Resort has the most successful ecotour program in terms of the number of ecotours $(1,250$ times a year) and the number of participants $(7,250$ people a year). In the survey, the average number of ecotours was 174.6 times a year and the average number of participants was 1,073.1 people. Saikai Pearl Sea Resort is located in the Kujukushima area of Saikai National Park, which consists of 208 islands. It is a third-sector organization established in 1994. Its facility consists of Kujukushima aquarium, excursion boats, restaurants, and shops. In 2009, 1,023,684 people visited the resort, which makes it the second most attractive tourism facility after Huis Ten Bosch in Nagasaki Prefecture. People visit the resort mainly for the aquarium or for cruising on large pleasure boats. Among 91 staff members, six members belong to an ecotour promotion office. Under the direction of the city, which formulated the Sasebo Ecotourism Guidelines, the resort participates in ecotourism, and the members of the ecotourism promotion office learn, plan, and implement ecotourism. When the office was established, members of the office did not know much about ecotourism. For example, they did not know the difference between tour guides and ecotour guides. However, they became experts on ecotourism through study and training, which included a visit to Unzen city, Nagasaki Prefecture. Unzen is known as a popular ecotourism site located in the Unzen-Amakusa National Park.

Currently, Saikai Pearl Sea Resort has seven ecotour programs. The first one is called "Kujukushima Relaxing Cruises", in which cruise passengers learn about landscapes and nature of the Kujukushima area with an ecotour guide in a relaxed atmosphere for 50 minutes. The second program is "Kujukushima Yacht Sailing", in which a yacht sails through the islands for an hour. The third program is called "Eco Boat 'Matsura"' and is a one-hour ecotour that uses a traditional skull-powered boat with a narration of Kujukushima stories by a boatman. The fourth ecotour program is a 45-minute "Sea Kayak" experience with a 10-minute lecture on kayaking. The fifth program is the "Island Walk", in which ecotour guides take tourists around the sea and uninhabited islands for three hours - a program that is popular among school children during summer break, and where they learn about plants, marine life, and insects through an ecotour guide. The sixth program is a half- 
Table 3. Saikai Pearl Sea Resort's programs and their rationale as ecotourism.

\begin{tabular}{ll}
\hline Ecotour program & Rationale as ecotourism \\
\hline 1. Kujukushima Relaxing Cruises & - Use of energy-efficient engine \\
& - Use of ecotour guide \\
2. Kujukushima Yacht Sailing & - No use of fossil fuel \\
3. Eco Boat "Matsura" & - No use of fossil fuel \\
& - Use of culture-tour guide \\
4. Sea Kayak & - No use of fossil fuel \\
5. Island Walk & - Use of ecotour guide \\
6. Kuroshima Island Tour & - Use of culture-tour guide \\
7. Ukujima Island Tour & - Use of culture-tour guide \\
\hline
\end{tabular}

day or one-day tour to the island of Kuroshima, unusual for the fact that many Catholics live there. Visitors use a hired taxi to tour the island and listen to the tour guide's explanation on the history and culture of the island. The last program is a two-day tour to Ukujima Island, and includes a guided tour by taxi on the flora, landscape, and lifestyles of the island.

These programs are promoted as ecotours by the ecotour promotion office for three reasons: less use of fossil fuel, use of ecotour guide, and use of culture-tour guide. Table 3 reveals the rationale for each program. The ecotours by Saikai Pearl Sea Resort are not an ideal type as set out in the definition of ecotourism. The programs use taxis and a relaxing boat to accommodate more tourists. This easy interpretation of ecotourism is a reason for its success in terms of the number of participants it attracts when compared to other ecotours in Kyushu.

The rationale indicates that ecotourism provided by Saikai Pearl Sea Resort emphasizes a cultural aspect. Although it looks very successful in contrast to other providers in terms of the number of tourists, according to a staff member, there are many difficulties in implementing ecotours when compared to regular tours. Basically, people do not understand what ecotourism is. Therefore, they are not popular among customers who come to the resort. In 2010, only 7,250 people participated in Kujukushima Relaxing Cruises, which is the most popular ecotour in the resort. Comparing the total number of visitors to the resort $(1,023,684$ people in 2009) with this figure reveals how unpopular ecotours are. Moreover, ecotours depend on the season, weather, and tides, factors that reduce the number of days they can operate. In addition, it is difficult to attract frequent visitors. Thus, as a business, it is difficult to generate profits through ecotourism.

In terms of the relationship between ecotours and the realization of a low-carbon society, most programs do not contribute much to the 
reduction of $\mathrm{CO}_{2}$ emissions. Only four programs actually reduce $\mathrm{CO}_{2}$ by using less or no fossil fuel while entertaining tourists. However, given the number of participants, its contribution is limited. The taxis used in the Kuroshima Island Tour and Ukujima Island Tour do emit $\mathrm{CO}_{2}$. If transportation to the resort is taken into account, these tours contribute to global warming, because $40 \%$ of the participants come from outside Kyushu (by airplane or train), and among visitors from within the Kyushu region, people from Fukuoka Prefecture form the largest group (coming by car or train).

Tourists coming to Saikai Pearl Sea Resort are typically mass tourists. They visit the aquarium, embark on pleasure boats, eat at restaurants, and buy souvenirs in shops at the resort. An ecotour is just one of the options in their activities. Therefore, this case is different from the "Yakushima" type and other "non-Yakushima" types. The case of the Saikai Pearl Sea Resort shows that even the most successful ecotours in Kyushu have difficulty in reducing $\mathrm{CO}_{2}$ emissions. However, it is their hope that ecotours will transform people's consciousness for seeking lifestyles compatible with a low-carbon society.

\section{Discussion and conclusions}

\subsection{What we know from the findings}

This study presents a review of the literature on the relationship between (eco)tourism and climate change, followed by qualitative research consisting of content analysis, a mail survey, and participant observation. The literature review of Western scholarship revealed that there is a relationship between ecotourism and global warming due to heavy reliance on air transportation to the destinations, whereas a relationship between ecotourism and the realization of low-carbon society is inconclusive. ${ }^{2}$ There is no substantial literature on the issue in the case of Japan; thus, original research was conducted. The findings show that there is a tenuous relationship between Japanese ecotourism and reduction of greenhouse gases because ecotour providers mainly rely on environmental education, which is intangible and hard to measure. In addition, in a mail survey, it was revealed that only two ecotour organizers actually implemented programs that reduce energy usage, that is, through the use of bicycles or walking as means of transportation. These ecotour programs are tangible, but have a very minor role in reducing $\mathrm{CO}_{2}$. There is a negative link between Japanese ecotourism and global warming, but it is variegated by the types of ecotourism. The three types of ecotourism studied use different modes of transportation and, consequently, generate different degrees of $\mathrm{CO}_{2}$ emissions. 
Table 4. The summary of the relationship between ecotourism and global warming.

\begin{tabular}{|c|c|c|}
\hline Types of ecotourism & $\begin{array}{l}\text { Relationship between } \\
\text { ecotourism and climate } \\
\text { change }\end{array}$ & Degree of impact \\
\hline Ecotourism in the West & $\begin{array}{l}\text { Positive } \\
\text { Negative }\end{array}$ & $\begin{array}{l}\text { Inconclusive } \\
\text { Large }\end{array}$ \\
\hline $\begin{array}{l}\text { Japanese ecotourism: } \\
\text { "Yakushima" type }\end{array}$ & $\begin{array}{l}\text { Positive } \\
\text { Negative }\end{array}$ & $\begin{array}{l}\text { Tenuous } \\
\text { Large }\end{array}$ \\
\hline "Mass tourism" type & $\begin{array}{l}\text { Positive } \\
\text { Negative }\end{array}$ & $\begin{array}{l}\text { Tenuous } \\
\text { Medium }\end{array}$ \\
\hline "Small non-Yakushima" type & $\begin{array}{l}\text { Positive } \\
\text { Negative }\end{array}$ & $\begin{array}{l}\text { Tenuous } \\
\text { Small }\end{array}$ \\
\hline
\end{tabular}

First, ecotourism to destinations such as Yakushima has a large negative impact on climate change owing to a reliance on air transportation. It is similar to the Western type of ecotourism. Second, ecotourism to destinations such as Saikai Pearl Sea Resort do not differ much from mass tourism in that ecotours offered there are not a primary attraction for the tourists but one of the options. Moreover, as a mass tourism type, it is conveniently located for tourists. Thus, unlike "Yakushima" type tourism, tourists use not only airplanes but also trains and cars. In this type, the negative impact of ecotourism on climate change is medium. Finally, the ecotourism type whose operation is small (unlike Saikai Pearl Sea Resort), and not in Yakushima, has a smaller impact on global warming. This is a type that attracts tourists not from Tokyo or Osaka but from within Kyushu, and thus $\mathrm{CO}_{2}$ emissions are the lowest among the three types. Table 4 summarizes these relationships derived from the literature review and my own findings.

The following sections discuss the characteristics of Japanese ecotourism that could answer the following two questions: "Why is the impact of ecotourism on global warming in the West large, ${ }^{3}$ while its impact in Japan is variegated?" and "Why is the relationship between Japanese ecotourism and the realization of a low-carbon society tenuous?"

\subsection{Difference in the definition of ecotourism}

Previous research and my own study indicate that the impact of ecotourism on global warming is large in the West, whereas Japanese ecotourism's impact on the environment varies. It is likely that the factors for this difference come from how the definitions of ecotourism were interpreted and the ways ecotourism was promoted. The United 
States is the largest ecotourism market (Kobayashi 2002: 44) ${ }^{4}$ and The International Ecotourism Society (TIES) in the United States defines it as "responsible travel to natural areas that conserves the environment and improves the well-being of local people" (TIES 1990). Australia is known as a country for advanced ecotourism practices (Kobayashi 2002: 224) and Ecotourism Australia, the major national body for the ecotourism industry, defines ecotourism as "ecologically sustainable tourism with a primary focus on experiencing natural areas that fosters environmental and cultural understanding, appreciation, and conservation" (Ecotourism Australia 2011). These definitions put nature as the primary attraction and the object to be conserved. Consideration for culture and people are secondary. The origin of ecotourism in the United States is nature tourism, a type of tourism wherein tourists learn and appreciate natural environments, such as wildlife and the working of nature. It started as a Sierra Club Outing Program in 1901. The legacy still influences the characteristics of contemporary ecotours, many of which offer visits to national parks by environmental NGOs. In Australia, ecotours that emphasize the natural environment also promote activities such as animal watching in Tasmania and touring on Fraser Island, an island of sand. The primary attractions of ecotours in the United States and Australia are unique natural habitats, and thus tourists have to travel to certain destinations, often distant, to experience them.

The definition of Japanese ecotourism is different. The Japan Ecotourism Society defines it as "travel that meets and interacts with local attractions" and describes its aim as "to activate local economies by providing tourists with opportunities to experience local attractions accompanied by competent interpreters while preserving local resources, such as natural environment, culture, and historical heritage" (JES 2011). In Japanese ecotourism, concern for local communities comes to the fore while concern for nature is secondary. Kaizu (2007: 4), a pioneer of ecotourism study in Japan, says, "ecotourism in Japan has established its style, the Japanese style". The trajectory of the development of ecotourism in Japan has been influenced by two factors. The first factor is what Hashimoto (1999: 266) calls "the spirit of conservation of nature", which is similar to the dominant component of the Western conceptualization of ecotourism. Japanese ecotourism has been influenced by this spirit, and ecotours to Yakushima, Shiretoko, and Ogasawara have magnificent attractions of this type. The second factor is the concern for local revitalization. This is what makes Japanese ecotourism different from the Western concept of ecotourism, which is characterized by a sizeable transport element that emits a significant volume of greenhouse gases (Simmons and Becken 2004). Unlike the 
United States and Australia, Japanese ecotourism, which does not necessarily require magnificent nature, can be practiced everywhere; therefore, the destination can be close to the tourists' point of origin. What is required is knowledge of the local culture, history, and landscape.

\subsection{Importance of local revitalization}

In Japan, ecotourism is used as an instrument to revitalize local communities. This is the major factor that differentiates Japanese ecotourism from ecotourism in the United States and Australia. Concern for local revitalization is a reflection of a Japanese reality in rural Japan, which is experiencing the shrinkage of community caused by a declining and aging population. According to the Ministry of Agriculture, Forestry, and Fisheries (MAFF 2010), between 1980 and 1990, a total of 2,255 communities lost their rural community functions, which include maintenance of rural resources, agricultural production support activities, and mutual assistance among community residents; and in the following decade, from 1990 to 2000, a total of 4,959 communities lost their rural community functions. According to Ohno (2008: 37-38), the number of marginal communities that have people older than 65 years of age making up more than $50 \%$ of their population was 7,878 in 2006. In addition, 191 communities disappeared between 1999 and 2006. It is estimated that 423 communities will disappear within 10 years and 2,220 communities will eventually disappear. Under these circumstances, ecotourism - and tourism in general - are viewed as promising tools to revitalize such communities. When implementing ecotourism focusing only on nature, the number of communities that have resources of untouched nature and special fauna and flora are limited. In Japan, especially, only a small number of virgin forests, such as Yakushima, Shirakami, and Shiretoko are left. Therefore, it is important to emphasize a cultural component of ecotourism in order to promote it.

This requirement was recognized in the Ecotourism Promotion Law enacted in 2008, which defines natural tourism resources not only as tourism resources related to habitats for fauna and flora and other natural environments but also as tourism resources that include traditions, customs, and way of life related to natural resources (Aichi and Moriyama 2008: 2). By this definition, ecotourism can be utilized in more communities. Japanese ecotourism, therefore, tends to be more inclusive of culture and closer to community development, which makes it different from the Western conception of ecotourism. For example, the Nihon ekotsua gaidobukku ('Japan ecotour guidebook') 
written by Kaizu (2007) includes a guided tour by bicycle in Kyoto (a city of about 1.5 million people). Therefore, local revitalization that originated from a concern for declining rural communities is extended to any community in Japan that wants to activate its economy. Thus, ecotourism is viewed as an additional income-generating activity in mass-tourism areas, such as Rokko and Sasebo. Actually, the Ministry of the Environment (MoE 2007: 4) differentiates ecotourism in Japan into three types: (i) ecotourism that is carried out in rich natural environments; (ii) ecotourism that is carried out in mass-tourism areas; and (iii) ecotourism that utilizes the natural environment near communities, local industries, and cultures of the local people.

The relative importance of local revitalization in Japanese ecotourism allows a wider range of tours to be categorized as ecotourism. For the purpose of analysis, Japanese ecotourism can be divided into three types, each with differences in the distance between the origination of tourists and tourism destinations as well as in the likely mode of transportation. Thus, the question of why the impact of ecotourism on global warming in the West is large, while its impact in Japan is variegated can be attributed to different trajectories of ecotourism development and different aims of ecotourism implementation. The second question of why the relationship between Japanese ecotourism and the realization of a low-carbon society is tenuous also can be answered by the purpose of Japanese ecotourism. Local revitalization is more important than environmental concern. Thus, the global issue of climate change is not perceived by ecotourism providers as a primary concern.

\subsection{Environmental education: the key to a low-carbon society}

Among ecotour providers in Kyushu, consumption of locally produced foods is the most popular category $(43 \%)$, and environmental education $(19 \%)$ is just one of the four minor categories that relate to the reduction of greenhouse gases in the content analysis. However, when asked a question about the general relationship between ecotourism and the realization of a low-carbon society, no one mentioned consumption of locally produced foods, and $78 \%$ of the providers thought that environmental education can contribute to the cause. When asked further about the relationship between the provider's specific ecotours and the realization of a low-carbon society, $87 \%$ of the organizations mentioned environmental education as their way to reduce greenhouse gases, and $13 \%$ of them referred to reduction of energy use.

The perception of Japanese ecotour providers is that environmental education is the most important way to realize a low-carbon society. 
As mentioned in Section 5.1, the effect of environmental education is long term and intangible, but this does not mean it has no impact. For example, after participating in an ecotour, a tourist may change his/her lifestyle to a more energy-efficient one. During the ecotour, the impact may not be positive, but the effect of the lifestyle change can be continuous and may result in a large outcome. What is required is a compelling narrative of greenhouse gas reduction that can be shared among ecotour guides, and will have a lasting impression on participants.

\subsection{Suggestions for future research}

This study explores the relationship between ecotourism and climate change in Japan, and analyzes it in comparison to Western scholarship. The research showed a tenuous positive relationship between ecotourism and combating climate change, while the research in Western ecotourism was inconclusive. In Japanese ecotourism, environmental education was emphasized as a way to realize a low-carbon society. In contrast, Western ecotourism has a large negative impact on climate change, while the negative effects of Japanese ecotourism vary, dependent on the type of ecotourism: the "Yakushima" type of ecotourism (i.e., traveling to the destination by airplane) has a large impact, the "mass tourism" type (i.e., use of airplanes and other means of transportation) has a medium impact, and the small "non-Yakushima" type (i.e., other means of transportation, excluding airplanes) has a small impact. This suggests that the difference between the impact of ecotourism on climate change in the West and Japan comes from different definitions of Western ecotourism and Japanese ecotourism. Another important point is that the emphasis on revitalization of local communities has influenced the development of different types of ecotourism in Japan.

Suggestions for future research include the following: First, empirical studies of ecotourism's positive impact on mitigating climate change in Western ecotourism should be conducted as it was inconclusive in the literature review conducted as part of this study. Second, measures of the effectiveness of environmental education in reducing greenhouse gases need to be developed. Third, Western ecotourism should be examined more precisely to create a more nuanced definition of types of ecotourism similar to Japanese ecotourism. Finally, scholars should examine the effectiveness of ecotourism for community revitalization. If local communities are not revitalized, the small "non-Yakushima" type of ecotourism, which has the smallest negative impact on climate change among the three, will likely disappear. 
Yukio Yotsumoto is a graduate of Soka University in Japan, where he received a bachelor's degree in economics in 1989. He earned a master's degree in agricultural extension education from the University of Georgia in 1994 and a Ph.D. in sociology from the University of Kentucky in 2002. Currently, he is Associate Professor of Asia-Pacific Studies at Ritsumeikan Asia Pacific University. He is interested in community development and tourism, and his recent publications include: "Profiles of hawkers working in Rizal Park, Manila, Philippines: Socioeconomic status, migration motivations, and the sale of goods", Ritsumeikan International Affairs, (2011) Vol. 10, pp. 303-320.

\section{Notes}

* I would like to thank the reviewers for valuable suggestions that clarified some of the discussion. This study was supported by an AY2010 Ritsumeikan Asia Pacific University Research Subsidy, "Technological managerial and sociological scenario to realize a low-carbon society" (Project Leader: Professor Nakata Yukihiko), and an AY2011 Ritsumeikan Asia Pacific University Research Subsidy, "Multi-dimensional research for the development of a low-carbon society" (Project Leader: Professor Tsukada Shunso).

1. http://ecotourism.jp.

2. The relationships were derived from the literature review only. This is a limitation of this study. Thus, empirical study on this topic needs to be conducted in the future.

3. When reviewing the issue of ecotourism and global warming in Western literature, I did not encounter any type of ecotourism that was directly comparable to Japanese ecotourism. Thus, here I used only one type, namely ecotourism in the West. Although this is beyond the scope of this study, it is recommended that empirical studies be conducted on whether there are different types of ecotourism in the West.

4. In this section, the United Kingdom and other European countries were excluded, because Western literature on ecotourism and climate change does not discuss these countries and the characteristics of ecotourism may be different among them. For example, in the case of the United Kingdom, ecotourism is equated with green tourism.

\section{References}

Aichi, Kazuo \& Masahito Moriyama. 2008. Ekotsūrizumu suishin-hō no kaisetsu [A commentary on the Ecotourism Promotion Law]. Tokyo: Gyōsei.

Asahi Shimbun. 2009. Kokuren de 25 pāsento sakugen sengen: Hatoyama inishiachibu teian $[25 \%$ reduction declared at the United Nations: Proposal by the Hatoyama Initiative]. 23 September. 1.

Asahi Shimbun. 2010. Nidai kōkū seizōgaisha Bōingu to Eabasu no hikitsuzuku toraburu: Kizu tsuku shinyō [Continuous troubles of Boeing and Airbus, two major airplane manufacturing companies: Damage to their reputation]. 17 November. 11.

Becken, Susanne. 2002. Analysing international tourist flows to estimate energy use associated with air travel. Journal of Sustainable Tourism 10 (2). 114-131. 
Becken, Susanne. 2007. Tourists' perception of international air travel's impact on the global climate and potential climate change policies. Journal of Sustainable Tourism 15 (4). 351-368.

Becken, Susanne. 2008. The UN Climate Change Conference, Bali: What it means for tourism. Journal of Sustainable Tourism 16 (2). 246-248.

Becken, Susanne \& John E. Hay. 2007. Tourism and climate change: Risks and opportunities. Clevedon, UK: Channel View.

Becken, Susanne \& Matthias Schellhorn. 2007. Ecotourism, energy use, and the global climate: Widening the local perspective. In James Higham (ed.), Critical issues in ecotourism: Understanding a complex tourism phenomenon, 85-101. Oxford: Elsevier.

Becken, Susanne \& David G. Simmons. 2005. Tourism, fossil fuel consumption and the impact on the global climate. In C. Michael Hall \& James Higham (eds.), Tourism, recreation and climate change, 192-208. Clevedon, UK: Channel View.

Bonner, Ricardo. 2005. Understanding the calculation of aircraft emissions (A supplement of the Third Quarter 2005 EcoCurrents newsletter). The International Ecotourism Society.

Buckley, Ralf. 2009. Evaluating the net effects of ecotourism on the environment: A framework, first assessment, and future research. Journal of Sustainable Tourism 17 (6). 643-672.

Dawson, Jackie, Emma J. Stewart, Harvey Lemilin \& Daniel Scott. 2010. The carbon cost of polar bear viewing tourism in Churchill, Canada. Journal of Sustainable Tourism 18 (3). 319-336.

Ecotourism Australia. 2011. What is Ecotourism? http://www.ecotourism.org.au/ index.asp (accessed 19 December 2011).

Goeldner, Charles R. \& J. R. Brent Ritchie. 2009. Tourism: Principles, practices, philosophies, 11th edn. Hoboken, NJ: John Wiley \& Sons.

Gössling, Stefan. 2000. Sustainable tourism development in developing countries: Some aspects of energy use. Journal of Sustainable Tourism 8 (5). 410-425.

Gössling, Stefan, C. Borgström-Hansson, O. Hörstmeier \& S. Saggel. 2002. Ecological footprint analysis as a tool to assess tourism sustainability. Ecological Economics 43. 199-211.

Gössling, Stefan C., John Broderick, Paul Upham, Jean-Paul Ceron, Ghislain Dubois, Paul Peeters \& Wolfgang Strasdas. 2007. Voluntary carbon offsetting schemes for aviation: Efficiency, credibility, and sustainable tourism. Journal of Sustainable Tourism 15 (3). 223-248.

Hall, C. Michael \& James Higham. 2005. Tourism, recreation, and climate change. Clevedon, UK: Channel View.

Hashimoto, Kazuya. 1999. Kankō jinruigaku no senryaku: Bunka no urikata, urarekata [The strategy of the anthropology of tourism: Ways to sell culture and ways culture is sold]. Kyoto: Sekaishisōsha.

Holden, Andrew. 2009. An introduction to tourism-environment relationships. In Jennifer Hill \& Tim Gale (eds.), Ecotourism and environmental sustainability: Principles and practice, 17-30. Surrey: Ashgate.

Hori, Masahiro. 2007. Kankyō kyōiku wa naze hitsuyō ka [Why is environmental education necessary?]. In Environmental Education Research Group, Yokohama National University (ed.), Kankyō kyōiku: Kiso to jitsusen [Environmental education: Foundations and practice], 1-28. Tokyo: Kyōritsu Shuppan.

Hunter, Colin. 2009. Thinking globally about ecotourism impact: The contribution of ecological footprint analysis. In Jennifer Hill \& Tim Gale (eds.), Ecotourism and environmental sustainability: Principles and practice, 31-48. Surrey: Ashgate. 


\section{Yukio Yotsumoto}

JES (Japan Ecotourism Society). 2011. What is ecotourism? http://www.ecotourism.jp (accessed 8 February 2011).

Kaizu, Yurie. 2007. Nihon ekotsuā gaidobukku [Japan ecotour guidebook]. Tokyo: Iwanami Shoten.

Kobayashi, Hiroko. 2002. Ekotsūrizumu te nani? Fureizā-tō kara hajimatsuta chōsen [What is ecotourism? A challenge started from Fraser Island]. Tokyo: Kawade Shobō Shinsha.

Kunori, Noriyasu \& Hirokazu Kobayashi. 2006. Jizoku kanō na shakai to jizoku kanō na kankō [Sustainable society, sustainable tourism]. Proceedings of Japan International Tourism Research (JITR) Annual Conference 2006. 297-298.

Kunori, Noriyasu \& Hirokazu Kobayashi. 2007a. Sasuteinaburu tsūrizumu-ron [The theory of sustainable tourism]. Proceedings of Japan Institute of Tourism Research Annual Conference 2007. 201-204.

Kunori, Noriyasu \& Hirokazu Kobayashi. 2007b. Jizoku kanō na kankō-ron: Yakushima e no kankō no LCA hyōka to tsūrizumu sangyō no gurīn-ka [Sustainable tourism-case study: Greening of tourism industry by life cycle assessment]. Proceedings of Japan Institute of Tourism Research Annual Conference 2007. $353-$ 354.

MAFF (Ministry of Agriculture, Forestry and Fisheries). 2010. 2009-nendo shokuryō, nōgyō, nōson hakusho [FY2009 annual report on food, agriculture and rural areas in Japan]. Tokyo: MAFF, Government of Japan.

Martha, Honey. 2008. Ecotourism and sustainable development, 2nd edn. Washington, DC: Island Press.

MoE (Ministry of the Environment). 2007. Chikyū no tame ni dekiru koto, ekotsūrizumu suishin gaido [What we can do for the planet: Ecotourism promotion guide]. Tokyo: MoE, Government of Japan.

Norberg-Hodge, Helena. 1998. Think global - eat local! Delicious ways to counter globalization. The Ecologist 28 (4). 208-215.

Ohno, Akira. 2008. Genkai shüraku to chiiki saisei [Marginal communities and the revitalization of the communities]. Kochi: Kochi Newspaper Company.

Penner, J. E., D. H. Lister, D. J. Griggs, D. J. Dokken \& M. McFarland. 1999. Aviation and global atmosphere: A special report of IPCC Working Group I and III. Cambridge: Cambridge University Press.

Scott, Daniel, Geoff Wall \& Geoff McBoyle. 2005. The evolution of the climate change issue in the tourism sector. In C. Michael Hall \& James Higham (eds.), Tourism, recreation and climate change, 44-62. Clevedon, UK: Channel View.

Shikida, Asami. 2009. Chikyū ondan-ka bōshi to atarashī kenkyū [The prevention of global warming and new tourism]. Kankō [Tourism] 494. 22-25.

Simmons, David \& Susanne Becken. 2004. The cost of getting there - Impacts of travel to ecotourism destinations. In R. Buckley (ed.), Environmental impacts of ecotourism (Ecotourism Series No. 2), 15-23. Wallingford: CAB International.

Stewart, Emma J. \& Dianne Draper. 2009. Environmental sustainability and cruise tourism in Arctic Canada. In Jennifer Hill \& Tim Gale (eds.). Ecotourism and environmental sustainability: Principles and practice, 89-108. Surrey: Ashgate.

Strasdas, Wolfgang. 2007. Voluntary offsetting of flight emissions: An effective way to mitigate the environmental impacts of long-haul tourism? http://cms.fh-eberswalde.de (last accessed 29 February 2012).

TIES (The International Ecotourism Society). 1990. What is ecotourism? http:// www.ecotourism.org/what-is-ecotourism (last accessed 29 February 2012).

Tsuzuki, Yoshiaki, Hidenobu Kunii, Hirofumi Itakura, Kimio Iino \& Tomiko Notsu. 2009. Shishido-ko, Nakaumi chiiki to ekotsūrizumu senshinchi to no hikaku kentō [Comparison between Lake Shinji and Nakaumi Area and some typical eco-tourism areas]. Kisui Iki Kenkyū [LAGUNA] 16. 7-12. 
UNIPCC (United Nations Intergovernmental Panel on Climate Change). 1990. IPCC First Assessment Report 1990 (FAR). Geneva: IPCC.

UNIPCC (United Nations Intergovernmental Panel on Climate Change). 1995. IPCC Second Assessment Report: Climate Change 1995 (SAR). Geneva: IPCC.

Watanabe, Teiji. 2004. Sangakuchi seitaikei no zeijyakusei to chisei seitaigaku kenkyū no genjyō, kadai [Fragility of mountain geoecosystem and the current status and agendas of geoecological studies]. Journal of Geography 113 (2). 180-190.

Wearing, Stephen \& John Neil. 2009. Ecotourism: Impacts, potentials and possibilities, 2nd edn. Oxford: Elsevier.

WTO (World Tourism Organization). 2003. Climate change and tourism. Proceedings of the 1st International Conference on Climate Change and Tourism. http:// sdt.unwto.org/sites/all/files/pdf/tunisia_finrep_en.pdf (last accessed 12 February 2012).

WTO \& UNEP (World Tourism Organization \& United Nations Environment Programme). 2008. Climate change and tourism: Responding to global challenges. Madrid: WTO. 
